\title{
L'infrastruttura sportiva e l'identità territoriale
}

\author{
Marco Ricciarini \\ Adelaide Tremori
}

Abstract

Il paper cerca di comprendere il valore dellinfrastruttura sportiva, sia come possibilità di riqualificazione urbana, sia in quanto parte dell'identità di un territorio. In particolare, si analizza l'importanza della rappresentazione e del disegno per la costruzione di una memoria collettiva, portando a sostegno della tesi il caso studio dello stadio Marcello Milani di Pistoia, rilevato e rappresentato dall'Università degli Studi di Firenze, tramite tecniche tradizionali e non. Tale rappresentazione è indispensabile all'analisi più attenta della struttura, ma permette anche di conservare e rendere concreto il senso di appartenenza e di identità da parte della comunità. Partendo da questo sentire collettivo, lo stadio di Pistoia potrebbe avere una nuova vita, diventare un vero e proprio community hub e aprirsi a nuove prospettive.

Parole chiave

identità, memoria, sport.
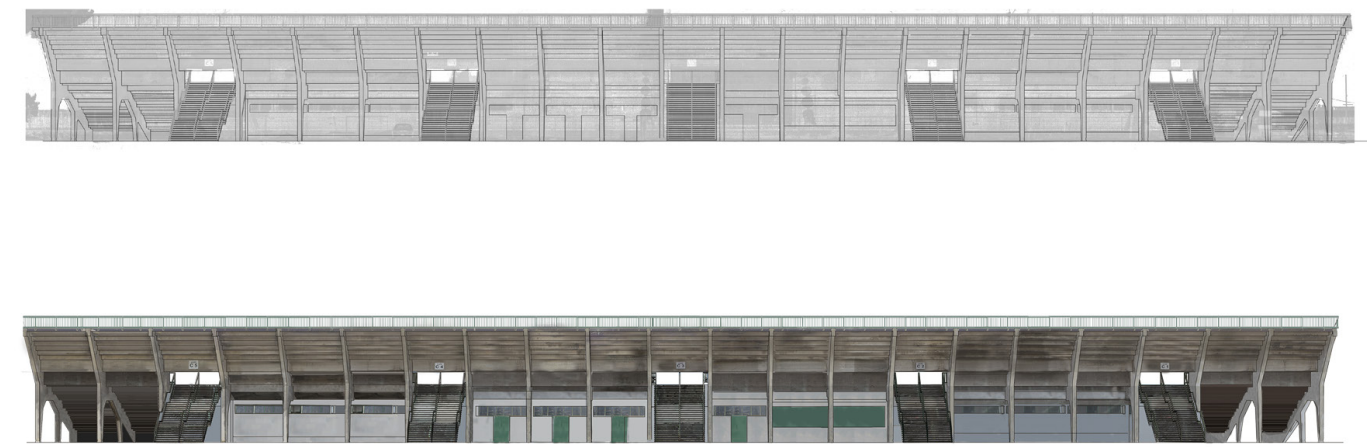


\section{Introduzione}

Il concetto di 'identità territoriale' è un concetto molto complesso da descrivere. Potremmo definirlo come il senso di appartenenza che un singolo prova verso un certo luogo, ma così facendo se ne sottolineerebbe solo il carattere individuale. In realtà l'identità territoriale è un sentire collettivo, che partecipa sia della società nella sua totalità, sia dell'individuo che ne fa parte; in altre parole l'identità territoriale deve tenere conto sia dell'identità del luogo, definita "sulla base delle rappresentazioni o immagini più condivise, a livello di gruppi e comunità, relative al luogo in questione" sia dell'identità di luogo, intesa come "quella parte dell'identità personale che deriva dall'abitare in specifici luoghi" [Banini 20I3, p. 9]. Inoltre, come in un singolo l'identità si va a costruire a partire dalla memoria autobiografica, così l'identità di un territorio è fatta da memorie, rappresentazioni e pensieri collettivi, da un passato comune e comunemente condiviso. In altre parole, è identità territoriale la cultura di una determinata comunità, le sue manifestazioni artistiche, spirituali, politiche e religiose. Mentre il singolo è in grado di richiamare alla mente la propria memoria, come può un'intera comunità percepire un ricordo comune? Attraverso le immagini. Solo se testimoniato da una rappresentazione tangibile un avvenimento, un concetto o persino un luogo possono continuare a essere rievocati e percepiti attivamente da una collettività ed entrare così a far parte dell'identità e della memoria collettiva. La collettività ha, quindi, bisogno di documentazione tangibile, di una rappresentazione grafica e visiva per poter riportare alla mente il passato.

Questa premessa è necessaria ai fini della seguente trattazione; il DIDA dell'università di Firenze ha, infatti, ricevuto l'incarico da parte dell'amministrazione comunale di Pistoia, di rilevare e rappresentare graficamente lo stadio della Pistoiese prima che questo subisse un rifacimento e un'importante ristrutturazione. II rilievo aveva sì lo scopo di poter quantificare le spese per l'abbattimento di alcune porzioni dello stadio, ma se questo fosse stato l'unico obbiettivo, l'incarico sarebbe risultato sterile e lo si sarebbe potuto affidare a un qualsiasi professionista. La partecipazione dell'Università ha dato, invece, la possibilità di riflettere su altre frontiere, sull'importanza dello stadio per la popolazione pistoiese, sul suo passato e la sua memoria, sulle possibilità per il futuro e la sua riqualificazione. Tali riflessioni sono però state possibili solo grazie alla rappresentazione e alla restituzione grafica, perché, proprio con questi strumenti, si è potuto indagare la memoria collettiva e chiedersi se l'architettura sportiva sia stata parte o meno dell'identità territoriale della zona.

\section{L'infrastruttura sportiva: parte della cultura collettiva?}

Può un'architettura destinata allo svago e allo sport essere considerata parte dell'identità collettiva?

Nel pensiero moderno, difficilmente la parola sport viene utilizzata per descrivere la nozione di cultura. In una definizione di questa parola ci si riferisce a concetti come l'arte, la politica, la religione ma difficilmente si farebbe riferimento alle pratiche sportive, come dimostra anche la definizione che la stessa Treccani dà di 'cultura': "complesso delle istituzioni sociali, politiche ed economiche, delle attività artistiche, delle manifestazioni spirituali e religiose, che caratterizzano la vita di una determinata società in un dato momento storico" [I]. Tuttavia, è innegabile che lo sport abbia fatto parte delle tradizioni e del patrimonio comune da tempi immemori; primi tra tutti, i greci diedero alle Olimpiadi la dignità di manifestazione culturale e non solo sportiva, conferendo allo sport una valenza religiosa, spirituale ed edu-

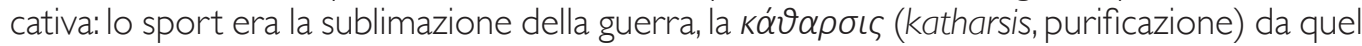
sentimento agonistico che accomuna tutti gli uomini. Tuttavia, la modernità, pur condividendo l'importanza dello sport e dell'attività fisica nella vita quotidiana, pare essersi dimenticata di questa sacralità che l'antichità gli aveva conferito e ha relegato lo sport ad un ruolo molto più marginale e di certo molto meno elevato.

Tuttavia, occorre notare che alcune architetture sportive, dal Colosseo al Circo Massimo, sono diventate parte del patrimonio collettivo e fanno parte della nostra identità e della nostra memoria, pur essendo destinate alla pratica sportiva. In antichità l'infrastruttura sportiva 
diventava un luogo vissuto, venerato, percepito sacro da tutta la collettività, non solo dalla tifoseria più fedele. Non bisogna, però, dimenticarsi che, insieme a monumenti di questo calibro, anche alcune strutture più moderne fanno ora parte dell'immagine della città e la loro mancanza ne cambierebbe i connotati in maniera irreversibile: l'Olimpico di Roma, il Franchi di Firenze, San Siro a Milano sono tutti monumenti dell'epoca contemporanea che fanno parte dell'immaginario di ognuno. Alla luce di queste considerazioni, è forse possibile asserire che l'infrastruttura sportiva può essere considerata parte dell'identità collettiva e in quanto tale merita una rappresentazione, che le conferisca imperitura memoria e che le permetta di aprirsi a nuovi utilizzi e nuovi scenari futuri. Anche nel caso dello stadio di Pistoia, seppur ad una scala ridotta, siamo davanti ad un esempio di architettura sportiva che fa parte della memoria collettiva; è stato, infatti, una struttura molto importante per la città, fortemente desiderata prima della sua costruzione e più volte ampliata e rimaneggiata per far fronte alla grande affluenza, in particolare nel periodo in cui la squadra della Pistoiese giocava in serie A. Negli ultimi anni, tuttavia, con la decadenza della squadra, lo stadio è stato progressivamente abbandonato e la capienza è stata ridotta a circa 2100 posti [Braccesi, 2019]. Ė interessante notare, però, come, nonostante la crisi della società calcistica e il silenzio delle autorità, i pistoiesi abbiano continuato a lottare per il loro stadio e l'opinione pubblica si sia spesso concentrata sulle sue sorti. II futuro di questa architettura non ha interessato solo i tifosi, ma la cittadinanza intera, tanto che adesso l'autorità comunale si è nuovamente approcciata al problema, con l'intento di porvi rimedio e di riportare lo stadio agli antichi fasti.

\section{L’appropriazione del passato: rappresentazione e documentazione}

Come accennato precedentemente, la rappresentazione è necessaria per la costruzione e la conservazione della memoria collettiva. Infatti, la parola storia (che possiamo qui intendere come il racconto del passato di una comunità) viene da iotopía, la ricerca, derivata dalla stessa radice etimologica indoeuropea dei verbi ópá $\omega$ e video, che hanno entrambi

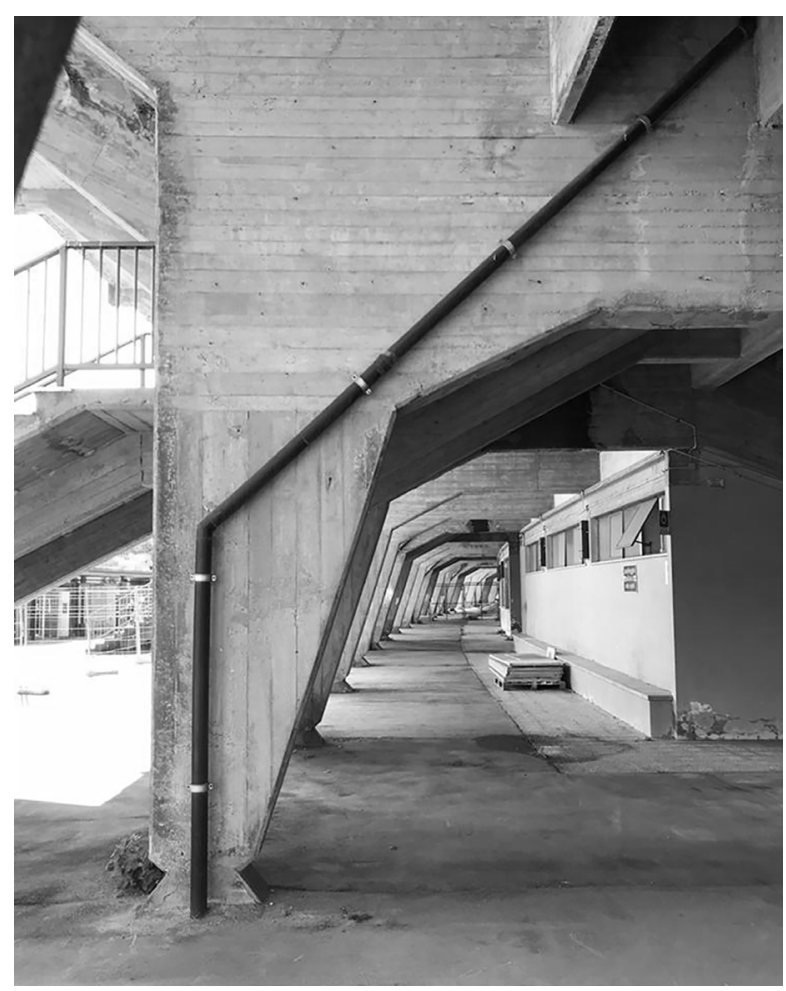


come primo significato quello di 'vedere'. La vista è quindi strettamente collegata alla costruzione della storia, della memoria e del ricordo. Ecco che anche in questo caso, poco prima della ristrutturazione e della demolizione dello stadio di Pistoia, si è resa necessaria una documentazione che rendesse possibile il mantenimento della memoria. Tale documentazione è stata portata avanti s̀ con alcune rappresentazioni grafiche tradizionali (schizzi, disegni e rilievo manuale), ma anche con nuove tecnologie, quali il rilievo con laser scanner e la fotogrammetria. II rilievo tramite laser scanner ha interessato la tribuna est, di cui era già stata predisposta la demolizione, ma anche il resto dello stadio e la restituzione grafica della nuvola di punti è stata poi eseguita tramite i software Cyclone, Recap e AutoCAD. La documentazione fotogrammetrica è invece stata rielaborata utilizzando Zephyr 3D e sono state raccolte anche alcune foto storiche dello stadio. I risultati di tali rielaborazioni sono poi stati raccolti in alcune tavole che sono state consegnate all'amministrazione comunale, della quale saranno a disposizione per ulteriori elaborazioni. L'utilizzo di tecnologie digitali permetterà una futura progettazione direttamente su piattaforma informatica, elemento che si spera possa incoraggiare uno sguardo al futuro. Infatti, una struttura che è patrimonio della collettività non può essere conservata per mera venerazione nei confronti del passato: un tale atteggiamento antiquario, nel senso nietzschiano del termine, cristallizza la realtà e paralizza il progresso.

\section{Guardare al futuro}

Giuseppe Dematteis e Francesca Governa hanno evidenziato come l'idea di identità territoriale coincida con l'incontro di tre diversi assi di analisi: "quello della coerenza interna, che rinvia alla differenza e al confine con l'altro; quello della continuità nel tempo, che chiama in causa memoria, tradizioni, abitudini, e quello della tensione teleologica, che si collega all'azione proiettata nel futuro" [Dematteis, Governa 2003]. L'identità territoriale, quindi, si forma sì con la memoria e la rappresentazione, ma si esplica concretamente nel suo sguardo al futuro. Ma può l'infrastruttura sportiva avere delle potenzialità in tal senso? $\bigcirc$ è destinata a rimanere confinata ad un utilizzo esclusivo durante le manifestazioni sportive e quindi ad avere un ruolo marginale nella vita cittadina?

A partire dal secondo dopoguerra, si è diffusa una pratica progettuale che tenta di aprire le aree sportive a nuovi orizzonti e a nuove funzioni in modo tale che tali luoghi possano acquisire un posto più attivo all'interno della vita cittadina. La problematica che oggi si presenta, però, è che, a causa delle sempre maggiori necessità di spazio, sicurezza, comfort e accessibilità, diventa difficile collocare gli stadi nel centro cittadino. Le nuove architetture sportive vengono, quindi, collocate fuori dai confini urbani, con il rischio che, benché dotate di ogni comfort (servizi di ristorazione, negozi, luoghi per lo svago e per il relax), di nuovo rimangano destinate a una frequentazione molto sporadica e legata solo agli eventi sportivi. È un esempio lampante di questa tendenza lo Juventus stadium, che, benché "un impianto di grande qualità dal punto di vista dell'accessibilità e della visibilità, fa fatica a vivere durante la settimana, non ha ancora sfondato sotto quell'aspetto" [2], secondo le parole dell'architetto Boeri. Nel presente caso di studio, però, la situazione è un po' diversa: lo stadio di Pistoia si trova in una posizione alquanto centrale, a pochi minuti a piedi da una delle piazze principali della città. Costituisce, quindi, un'opportunità importante per lo sviluppo di Pistoia, sia dal punto di vista economico, che da quello sociale. Lo stadio di Pistoia, seguendo un trend sempre più frequente nella progettazione urbanistica, potrebbe trasformarsi in un vero e proprio community hub, uno spazio fisico che mette al centro la relazione persone-comunità. All'interno dei community hub sono erogati servizi molto diversi tra loro (programmi culturali, servizi di welfare e per il tempo libero), che, però, hanno come comune intento quello di moltiplicare la comunicazione, le occasioni di scambio, la condivisione. Le infrastrutture sportive, per la loro estensione, ma anche per la natura stessa dello sport, si prestano in maniera particolare a questo scopo. Infatti, lo sport rappresenta un importante momento di socializzazione, di scambio, ma anche di integrazione: parla un linguaggio universale, che può da tutti essere capito e condiviso. Non a caso sul libro bianco della Commissione delle 
Comunità Europee, si può leggere tra le dichiarazioni di intenti: "Utilizzare il potenziale dello sport per l'inclusione sociale, l'integrazione e le pari opportunità. Lo sport contribuisce in modo significativo alla coesione economica e sociale e a una società più integrata. Tutti i componenti della società dovrebbero avere accesso allo sport [...]. Lo sport promuove un senso comune di appartenenza e partecipazione e può quindi essere anche un importante strumento d'integrazione degli immigrati". Si asserisce poi che "Le attività sportive senza scopo di lucro che contribuiscono alla coesione sociale e all'inserimento sociale delle categorie vulnerabili possono essere considerate servizi sociali d'interesse generale".

Alla luce di queste affermazioni, pare chiara la possibilità di sfruttare le infrastrutture sportive come occasione per la rigenerazione urbana, poiché riqualificare questi spazi può voler dire dare un nuovo volto alla città, mantenendone, però, intatto il disegno complessivo e non dimenticandosi del passato di questi luoghi.

\section{Conclusioni}

II rilievo realizzato dall'Università di Firenze permette ora di avere una rappresentazione chiara e precisa dello Stadio. Allo stesso tempo ha rappresentato un'occasione per ripercorrere la storia di una vera e propria istituzione di Pistoia. Rappresenta un punto di arrivo e un punto di partenza per lo stadio Marcello Melani. Il punto di arrivo di una lunga tradizione che parte dall'inizio del Novecento e arriva fino ai giorni nostri; un punto di partenza che apra a nuove prospettive e nuove possibilità.

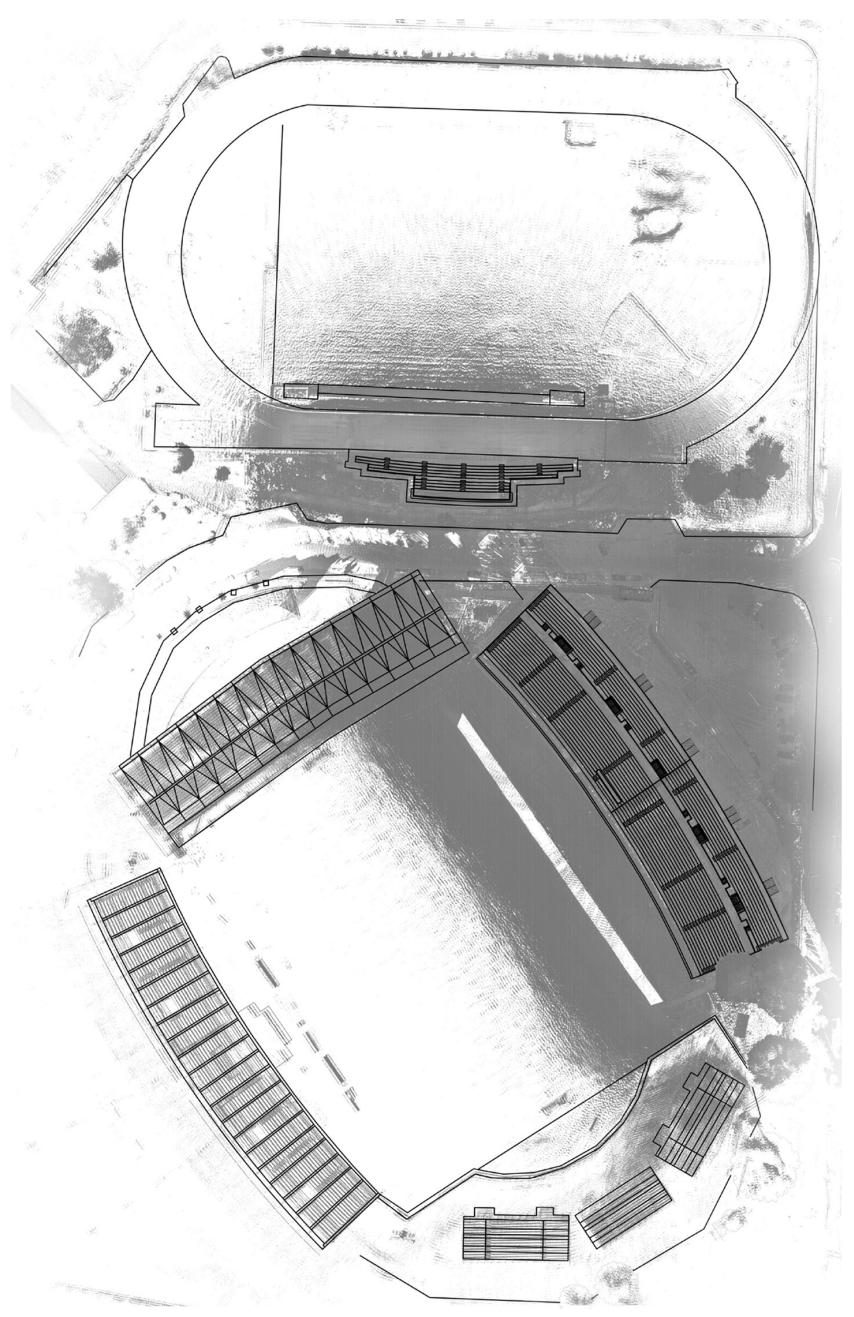


Fig. 3. Immagini ottenute dallelaborazione in seguito al riliev punti in seguito al rilievo con strumentazione documentazione di tale struttura è stata necessari struttura e stata necessar per comprendere il re
costo di demolizione dell'intera tribuna.
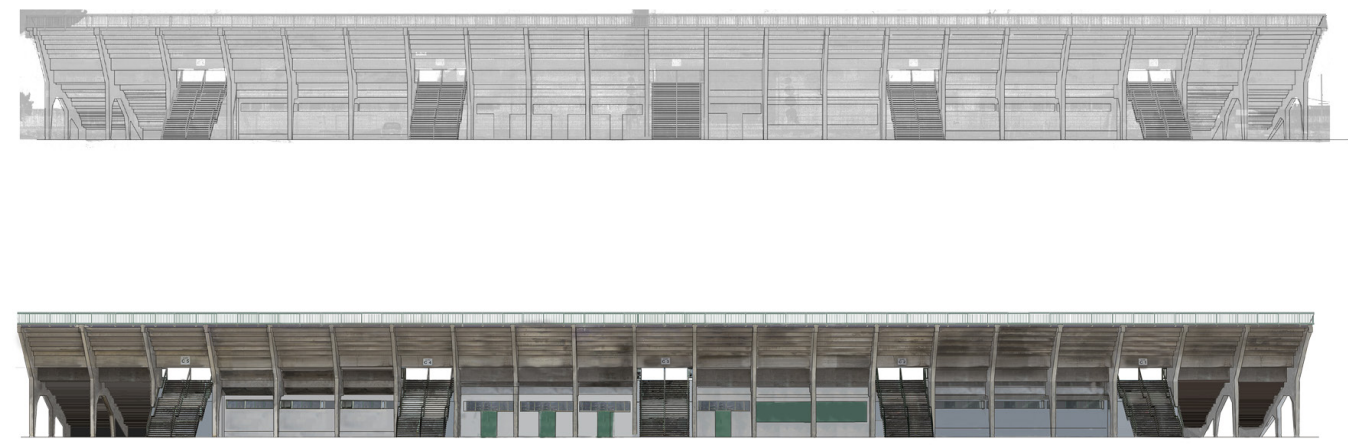

\section{Note}

[I] 'Cultura', ad vocem, Enciclopedia Treccani: <http://www.treccani.it/vocabolario/cultura/>.

[2] F. Casotti, DOSSIER STADI - Boeri: "Gli stadi in Italia, scatole vuote. Allianz Arena esempio da imitare, San Siro lo ripenserei così... ": <https://www.goal.com/it/news/2/serie-a/20 I 5/02/20/9106822/dossier-stadi-boeri-gli-stadi-in-italia-scatole-vuote> .

\section{Riferimenti bibliografici}

Ariante Francesca (20 I6). Comunicare e costruire l'identità: ruolo della memoria nella costruzione del sé.Tesi di Laurea 20 I 5-20 I6. Università degli Studi Suor Orsola Benincasa.

Banini Tiziana (2013). Identità territoriali. Questioni, metodi, esperienze a confronto. Milano: Franco Angeli.

Bonesio Luisa (20 I2). La questione epistemologica e il linguaggio. In Magnaghi Alberto (a cura di). II territorio bene comune. Firenze: Firenze University Press.

Dematteis Giuseppe, Governa Francesca (2003). Ha ancora senso parlare di identità territoriale? In De Bonis Luciano (a cura di). La nuova cultura delle città. Roma: Accademia Nazionale dei Lincei.

Dematteis Giseppe, Governa Francesca (2003). Territorialità, sviluppo locale, sostenibilità: il modello SLOT. Roma: Franco Angeli.

Fimiano Valentina (20 I6). La memoria collettiva europea. Tesi di Laurea Centro studi europei, Salerno: Università degli Studi di Salerno.

Morri Riccardo, Maggioli Marco (2009). Periferie urbane: tra costruzioni dell'identità e memoria. In Agei Geotema, n. 37, 2009.

Scarpetta Sabrina (2007). La filosofia dello sport nell'antica Grecia. Laboratorio Montessori, White paper on sport, Bruxelles.

\section{Sitografia}

Casotti Federico, DOSSIER STADI - Boeri: "Gli stadi in Italia, scatole vuote. Allianz Arena esempio da imitare, San Siro lo ripenserei così...": <https://www.goal.com/it/news/2/serie-a/20 15/02/20/9106822/dossier-stadi-boeri-gli-stadi-in-italia-scatolevuote>

Donaggio Elena, Pizzocchero Giovanni, Sarti Emma (2017). Sport e community hub: lo sport come valore per la comunità: $<$ https://www.avanzi.org/sport/sport-e-community-hub-lo-sport-come-valore-per-la-comunita>

Donaggio Elena (2017). Sport e rigenerazione urbana: ripensare gli impianti sportivi: <https://www.arcipelagomilano.org/ archives/45609>.

\section{Autori}

Marco Ricciarini, Università degli Studi di Firenze, marco.ricciarini@unifi.it

Adelaide Tremori, Università degli Studi di Firenze, adelaide.tremori@stud.unifi.it

Per citare questo capitolo: Ricciarini Marco, Tremori Adelaide (2020). L'infrastruttura sportiva e l'identità territoriale/Sports infrastructure and territorial identity. In Arena A., Arena M., Brandolino R.G., Colistra D., Ginex G., Mediati D., Nucifora S., Raffa P. (a cura di). Connettere. Un disegno per annodare e tessere. Atti del $42^{\circ}$ Convegno Internazionale dei Docenti delle Discipline della Rappresentazione/Connecting. Drawing for weaving relationships. Proceedings of the 42th International Conference of Representation Disciplines Teachers. Milano: FrancoAngeli, pp. 2662-2673. 


\title{
Sports Infrastructure and Territorial Identity
}

\author{
Marco Ricciarini \\ Adelaide Tremori
}

\section{Abstract}

The paper tries to understand the value of the sport facilities, both as a possibility of urban redevelopment and as part of the identity of the territory. In particular, it analyses the importance of representation and design for the creation of a collective memory. To support the thesis, we bring the example of the Marcello Melani Stadium in Pistoia, surveyed and developed by the University of Florence, using traditional and non-traditional techniques. This representation is essential for a more careful analysis of the structure, but also guarantees that the sense of belonging and identity on the part of the community is preserved and made concrete. Starting from this collective feeling, the Pistoia Stadium could have a new life, become a real community hub, and open up to new perspectives.

Keywords

identity, memory, sport.
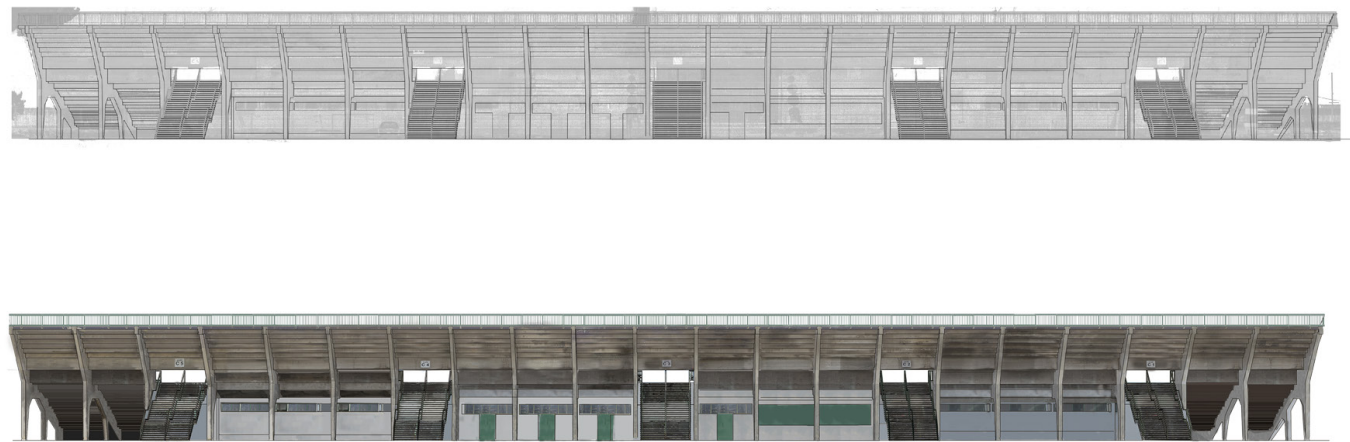


\section{Introduction}

The idea of territorial identity is a very complex notion to describe. We could define it as the sense of belonging that a person feels for a certain place, but, in this way, we would only underline its individual character. Actually, territorial identity is a collective feeling, which refers both to society as a whole and to the person who is part of it. In other terms, territorial identity include both the concept of the identity of the place, defined "on the basis of the most shared representations or images, at the level of groups and communities, relating to the place in question" and of the identity of the place, meaning "that part of personal identity that derives from living in specific places" [Banini 20 I3]. Furthermore, just as a single person's identity is built from the autobiographical memory, so the identity of a territory is made up of memories, representations and collective thoughts, from a common and shared past. In other terms, the culture of a particular community, its artistic, spiritual, political and religious manifestations are territorial identity. While the individual is able to recall his memory, how can an entire community perceive a common memory? It is possible through the images. Only if an event, a concept or even a place are shown by a tangible representation, we can continue to recall and perceive them and they can become part of the collective identity and memory. The community therefore needs tangible documentation, a graphic and visual representation in order to bring the past to mind.

This assumption is necessary for the purposes of the following discussion; the DIDA of the University of Florence has, in fact, been commissioned by the municipal administration of Pistoia to detect and graphically represent the Pistoia stadium before it underwent a big makeover. The survey had the purpose of quantifying the costs for the demolition of some portions of the stadium, but if this had been the only goal, the assignment would have been sterile and could have been entrusted to any professional figure. The participation of the University gave, however, the opportunity to reflect on other topics, on the importance of the stadium for the population of Pistoia, on its past and its memory, on the possibilities for the future and its redevelopment. However, these reflections were possible only thanks to the graphic representation, because, by this medium, it was possible to investigate the collective memory and wonder if the sports architecture was part or not of the territorial identity of the area.

\section{Is the sport architecture part of the collective culture?}

Can a sport architecture be considered part of the collective identity?

In a definition of culture, we refer to concepts such as art, politics, religion but the word sport is hardly used to describe the notion, as also Treccani's definition of 'culture' demonstrates: "complex of social institutions, political and economic, of artistic activities, of spiritual and religious manifestations, which characterize the life of a particular society in a given historical moment" [I]. However, it is undeniable that sport has been part of the common traditions and heritage since ancient time; first of all, the Greeks gave the Olympics the dignity of a cultural event, giving sport a religious, spiritual and educational value: sport was the sublimation of war, the $\kappa \alpha \dot{\vartheta} \alpha \rho \sigma \iota \varsigma$ (katharsis, purification) from that competitive feeling that unites all human beings. Despite sharing the importance of sport and physical activity in daily life, modernity seems to have forgotten this sacredness that antiquity had given to it and has relegated sport to a much more marginal role.

It should be noted that some sports architecture, from the Colosseum to the Circus Maximus, have become part of the collective heritage and are part of our identity and our memory. In ancient times the sports infrastructure became a lived, revered, perceived sacred by the whole community place. However, we shouldn't forget that, together with these ancient monuments, even some more modern structures are now part of the image of the city and their absence would change urban characteristics irreversibly: the Olimpico of Rome, the Franchi of Florence, San Siro in Milan are all monuments of the contemporary era that are part of everyone's imagination. Considering that, it is possible to say that sports 
architecture can be considered part of the collective identity. As part of the territorial identity, it deserves a representation, which gives it imperishable memory and which allows it to open up to new uses and new future scenarios. Even in the case of the Pistoia Stadium, we are approaching an example of sports architecture that is part of the collective memory; it was, in fact, a very important structure for the city, strongly desired before its construction and several times enlarged and remade, particularly in the period in which the team from Pistoia played in Serie A. In recent years however, with the decline of the team, the stadium was gradually abandoned, and the capacity was reduced to around 2100 seats [Braccesi 2019]. It is interesting to note, however, that, despite the crisis of the football club and the silence of the authorities, the pistoians continued to fight for their stadium and the public opinion has often focused on its fate. The future of this architecture has not only affected the fans, but the entire citizenship, to the point that now the municipal authority has once again approached the problem, with the intent of bringing the stadium back to its former glory.

\section{Appropriation of the past: representation and documentation}

As mentioned above, representation is necessary for the construction and conservation of collective memory. In fact the word history (which we can refer to as the story of the past of a community) came from i $\sigma \tau$ topi $\alpha$ (the research), derived from the same Indo-European etymological root of the verbs ó $\alpha \dot{\omega} \omega$ and video, which both have the meaning of to see.The view is therefore strictly connected to the construction of history and of memory. Also in this case, just before the restructuring and demolition of the Pistoia stadium, documentation was necessary for maintaining the memory. This documentation was carried out with some traditional graphic representations (sketches, drawings and manual survey), but also with new technologies, such as laser scanner survey and photogrammetry. The survey using laser scanners affected the east tribune, whose demolition had already been prepared, but also the rest of the stadium. The graphic rendering was performed through the Cyclone, Recap and AutoCAD softwares. The photogrammetric documentation was instead reworked

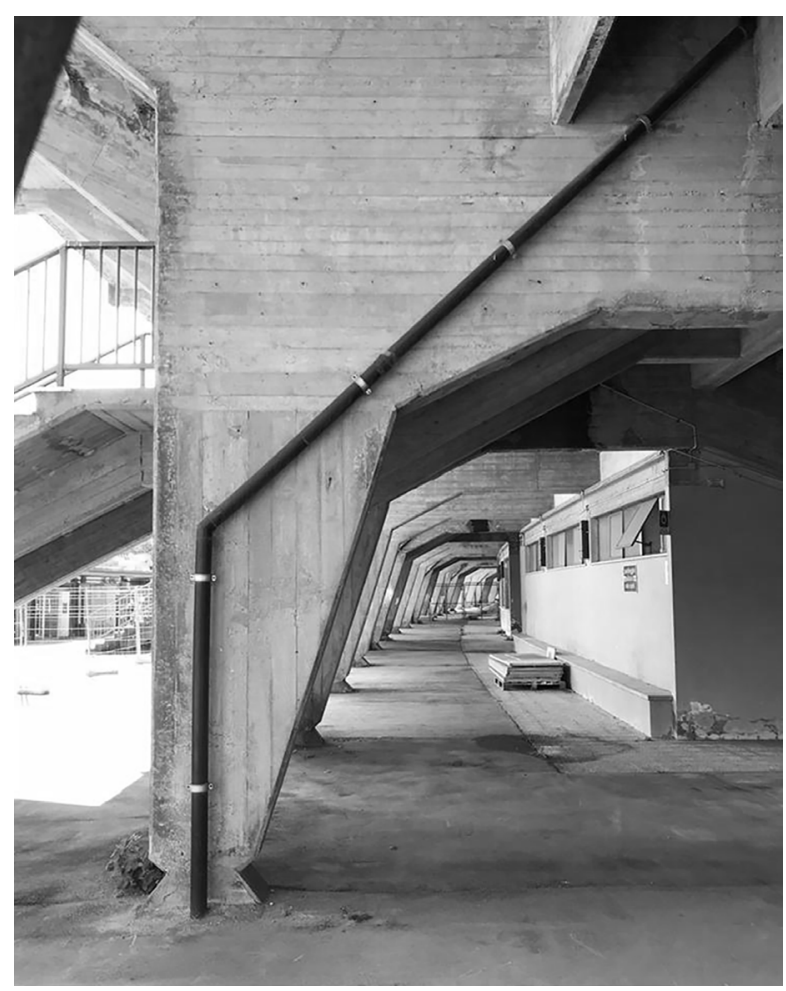


using Zephyr 3D and some historical photos of the stadium were collected too. The results of these process were then collected in some tables which were handed over to the municipal administration. The use of digital technologies will allow future design directly on the IT platform, a fact that will hopefully encourage a future development. In fact, a structure that is part of the heritage of the community cannot be preserved for mere reverence for the past: such an antiquarian attitude, in the Nietzschean sense of the term, crystallizes reality and paralyzes progress.

\section{A look into the future}

Giuseppe Dematteis and Francesca Governa have highlighted how the idea of territorial identity coincides with the meeting of three different axes of analysis: "that of internal coherence, which refers to the difference and the contact with the others; that of continuity over time, which calls into memory, traditions, habits; and that of teleological tension, which is connected to the action projected into the future" [Dematteis, Governa 2003]. Territorial identity, therefore, is formed with memory and representation, but is concretely expressed by its gaze to the future. Can sport infrastructure have potential in this regard? Or is it destined to remain confined to exclusive use during sporting events and therefore to play a marginal role in city life?

Starting from the second post-war period, a design practice that tries to open sport areas to new horizons and new functions has spread so that these places can acquire a more active place within city life. The contemporary problem, however, is that, due to the increasing need for space, safety, comfort and accessibility, it becomes difficult to place the stadiums in the city centre. The new sport architectures are placed outside the urban boundaries, with the risk that, although equipped with every comfort (catering services, shops, places for recreation and relaxation), they remain destined for very sporadic attendance. The Juventus stadium is a remarkable example of this trend, because "although a high-quality facility in terms of accessibility and visibility, it is difficult to live during the week, it has not yet broken through in that aspect" [2] according to the words of the architect Boeri. In the present case study, however, the situation is a little different: the Pistoia stadium is located in a central position, just a few minutes walk from one of the main squares in the city. It constitutes an important opportunity for the development of Pistoia, both economically and socially. The Pistoia stadium, following an increasingly frequent trend in urban planning, could become a true community hub, a physical space that focuses on the people-community relationship. Within the community hubs, very different services are provided (cultural programs, welfare and leisure services), which, however, have as common purpose that of multiplying communication, opportunities for sharing opinions. The sport infrastructures, for their extension, but also for the nature of the sport, are particularly suitable for this purpose. In fact, sport represents an important moment of socialization, exchange, but also of integration: it speaks a universal language, which can be understood and shared by everyone. It is no coincidence that in the white paper of the Commission of the European Communities, one can read among the declarations of intent: "Using the potential of sport for social inclusion, integration and equal opportunities. Sport contributes significantly to economic and social cohesion and to a more integrated society. All members of society should have access to sport [...]. Sport promotes a common sense of belonging and participation and can therefore also be an important tool for the integration of immigrants". It is then claimed that "non-profit sports activities that contribute to social cohesion and the social inclusion of vulnerable categories can be considered social services of general interest".

According to these statements, the possibility of exploiting sports infrastructures as an opportunity for urban regeneration seems evident. Redeveloping these spaces can mean giving a new face to the city, while keeping the overall design intact and not forgetting the past of these places. 


\section{Conclusion}

The survey made by the University of Florence has granted a clear and precise representation of the stadium. At the same time, it represented an opportunity to retrace the history of an institution in Pistoia. It represents a point of arrival and a starting point for the Marcello Melani Stadium: the arrival point of a long tradition that starts from the beginning of the twentieth century and goes up to the present day; a starting point that opens up to new perspectives and new possibilities.

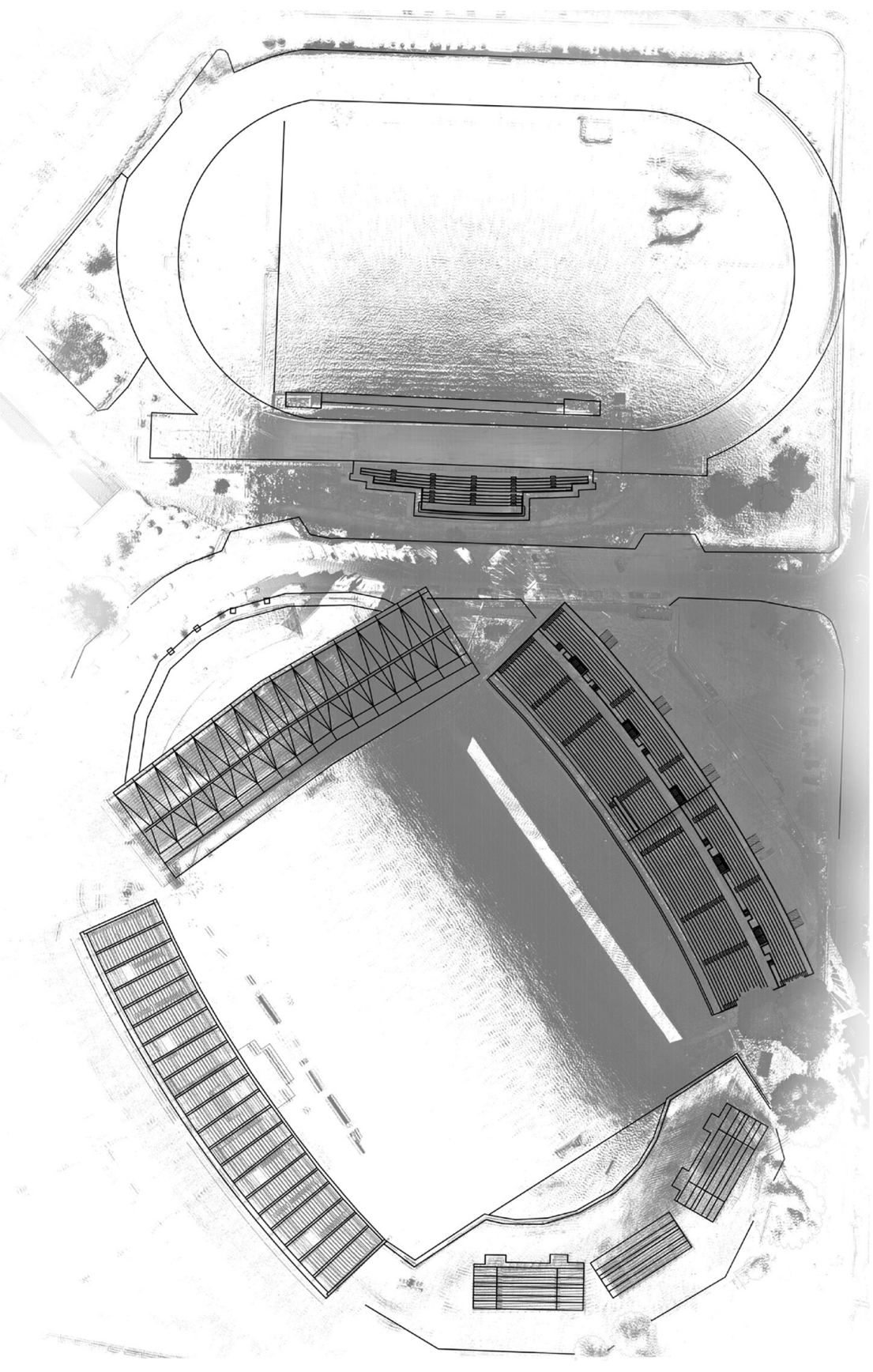


Fig. 3. Images obtained from point cloud processing after laser scanner instrumentation. scanner instrumentation The documentation necessary to understand necessary to und demolition of the entire grandstand.
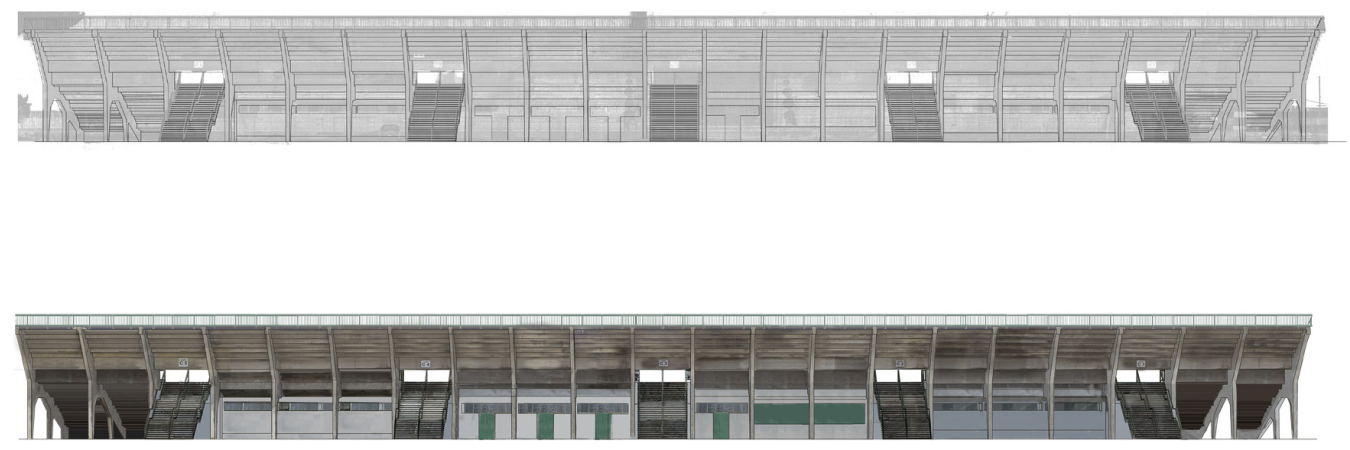

Notes

[I] 'Cultura', ad vocem, Enciclopedia Treccani: <http://www.treccani.it/vocabolario/cultura/>.

[2] F. Casotti, DOSSIER STADI - Boeri: "Gli stadi in Italia, scatole vuote. Allianz Arena esempio da imitare, San Siro lo ripenserei così...": <https://www.goal.com/it/news/2/serie-a/20 I 5/02/20/9 |06822/dossier-stadi-boeri-gli-stadi-in-italia-scatole-vuote>.

\section{References}

Ariante Francesca (20 I6). Comunicare e costruire l'identità: ruolo della memoria nella costruzione del sé. Tesi di Laurea 20 I 5-20 I6. Università degli Studi Suor Orsola Benincasa.

Banini Tiziana (20 I3). Identità territoriali. Questioni, metodi, esperienze a confronto. Milano: Franco Angeli.

Bonesio Luisa (20 I2). La questione epistemologica e il linguaggio. In Magnaghi Alberto (a cura di). II territorio bene comune. Firenze: Firenze University Press.

Dematteis Giuseppe, Governa Francesca (2003). Ha ancora senso parlare di identità territoriale? In De Bonis Luciano (a cura di). La nuova cultura delle città. Roma: Accademia Nazionale dei Lincei.

Dematteis Giseppe, Governa Francesca (2003). Territorialità, sviluppo locale, sostenibilità: il modello SLOT. Roma: Franco Angeli.

Fimiano Valentina (20 I6). La memoria collettiva europea. Tesi di Laurea Centro studi europei, Salerno: Università degli Studi di Salerno.

Morri Riccardo, Maggioli Marco (2009). Periferie urbane: tra costruzioni dell'identità e memoria. In Agei Geotema, n. 37, 2009.

Scarpetta Sabrina (2007). La filosofia dello sport nell'antica Grecia. Laboratorio Montessori, White paper on sport, Bruxelles.

Sitografia

Casotti Federico, DOSSIER STADI - Boeri: "Gli stadi in Italia, scatole vuote. Allianz Arena esempio da imitare, San Siro lo ripenserei cosi....": <https://www.goal.com/it/news/2/serie-a/20 15/02/20/9106822/dossier-stadi-boeri-gli-stadi-in-italia-scatolevuote>.

Donaggio Elena, Pizzocchero Giovanni, Sarti Emma (2017). Sport e community hub: lo sport come valore per la comunità: <https://www.avanzi.org/sport/sport-e-community-hub-lo-sport-come-valore-per-la-comunita>.

Donaggio Elena (2017). Sport e rigenerazione urbana: ripensare gli impianti sportivi: <https://www.arcipelagomilano.org/ archives/45609>.

\section{Authors}

Marco Ricciarini, Università degli Studi di Firenze, marco.ricciarini@unifi.it

Adelaide Tremori, Università degli Studi di Firenze, adelaide.tremori@stud.unifi.it

To cite this chapter: : Ricciarini Marco, Tremori Adelaide (2020). L'infrastruttura sportiva e l'identità territoriale/Sports infrastructure and territorial identity. In Arena A., Arena M., Brandolino R.G., Colistra D., Ginex G., Mediati D., Nucifora S., Raffa P. (a cura di). Connettere. Un disegno per annodare e tessere. Atti del $42^{\circ}$ Convegno Internazionale dei Docenti delle Discipline della Rappresentazione/Connecting. Drawing for weaving relationships. Proceedings of the 42th International Conference of Representation Disciplines Teachers. Milano: FrancoAngeli, pp. 2662-2673. 